\title{
On-Board Hydrogen Storage System Using Metal Hydride
}

by

$$
\text { CONF-970860--1 }
$$

L. K. Heung

Westinghouse Savannah River Company

Savannah River Site

Aiken, South Carolina 29808

A document prepared for HYPOTHESIS II HYDROGEN POWER, THEORETICAL AND ENGINEERING SOLUTIONS, INTERNATIONAL SYMPOSIUM at Grimstad, , Norway from 8/18/97 - 8/22/97.

DISTRIBUTION OF THIS DOCUMENT IS UNLIMITED

DOE Contract No. DE-AC09-96SR18500

This paper was prepared in connection with work done under the above contract number with the U.S. Department of Energy. By acceptance of this paper, the publisher and/or recipient acknowledges the U. S. Government's right to retain a nonexclusive, royalty-free license in and to any copyright covering this paper, along with the right to reproduce and to authorize others to reproduce all or part of the copyrighted paper. 


\section{DISCLAIMER}

This report was prepared as an account of work sponsored by an agency of the United States Government. Neither the United States Government nor any agency thereof, nor any of their employees, makes any warranty, express or implied, or assumes any legal liability or responsibility for the accuracy, completeness, or usefulness of any information, apparatus, product, or process disclosed, or represents that its use would not infringe privately owned rights. Reference herein to any specific commercial product, process, or service by trade name, trademark, manufacturer, or otherwise does not necessarily constitute or imply its endorsement, recommendation, or favoring by the United States Government or any agency thereof. The views and opinions of authors expressed herein do not necessarily state or reflect those of the United States Government or any agency thereof.

This report has been reproduced directly from the best available copy.

Available to DOE and DOE contractors from the Office of Scientific and Technical Information, P. O. Box 62, Oak Ridge, TN 37831; prices available from (423) 576-8401.

Available to the public from the National Technical Information Service, U. S. Department of Commerce, 5285 Port Royal Road, Springfield, VA 22161. 


\section{DISCLAMMER}

Portions of this document may be illegible in electronic image products. Images are produced from the best available original document. 
WSRC-MS-96-0780

\title{
ON-BOARD HYDROGEN STORAGE SYSTEM USING METAL HYDRIDE
}

\author{
L. K. Heung \\ Westinghouse Savannah River Company \\ 773-A, Savannah River Site, Aiken, SC 29808, USA \\ Phone: 803-725-3161 Fax: 803-725-2756
}

\begin{abstract}
A hydrogen powered hybrid electric bus has been developed for demonstration in the normal city service of the city of Augusta, Georgia, USA. The development team, called the H2Fuel Bus Team, consists of representatives from government, industry and research institutions. The bus uses hydrogen to fuel an internal combustion engine which drives an electric generator. The generator runs the electric motor to drive the bus. The batteries store the excess energy from the generator when the power demand is low and supply the additional energy when the power demand is high. The hydrogen fuel and the hybrid concept combine to achieve the goal of near-zero emission and high fuel efficiency. The hydrogen fuel is stored in a solid form using an on-board metal hydride storage system. The system was designed for a hydrogen capacity of up to $25 \mathrm{~kg}$. It uses the engine coolant for heat to generate a discharge pressure of up to $10 \mathrm{~atm}$. Other key operation parameters are temperature from ambient to $70^{\circ} \mathrm{C}$, hydrogen discharge rate to $6 \mathrm{~kg} / \mathrm{hr}$, and refueling time 1.5 hours. Preliminary tests showed that the performance of the on-board storage system exceeds the design requirements. This paper discusses the design and performance of the on-board hydrogen storage system.
\end{abstract}

\section{Introduction}

Hydrogen is widely considered to be the fuel of the future, mainly because it is renewable and burns cleanly. For vehicular applications, hydrogen can be used in internal combustion (IC) engines or in fuel cells. IC engines are less efficient than fuel cells in converting hydrogen to useful energy. However, IC engines are more economical than the fuel cells at the present time and, therefore are suited for hydrogen fuel demonstration in vehicles. When the cost of fuel cell improves, it will probably become the technology of choice. For either IC engines or fuel cells, on-board storage of hydrogen will be needed. Hydrogen can be stored as compressed gas, cryogenic liquid, or solid such as metal hydrides. Each of those storage techniques has its advantages and disadvantages, which need not be discussed here. However, it should be mentioned that metal hydrides offer a safety advantage, since the hydrogen is stored at a low pressure and at ambient temperature, and is not released until heat is applied. This is one of the reasons that study of metal hydrides for on-board hydrogen storage started in the early seventies, and is continuing today ${ }^{1,2}$. Due to the large number of metal hydrides available and 
the different requirements for different applications, the challenge has been to select the best metal hydride and to design the best storage vessel for a specific application.

\section{H2Fuel Project at Savannah River Site}

After the cold war, the US Department of Energy (DOE) initiated a technology transfer effort. The purpose was to transfer technology developed in the DOE owned laboratories to industry to promote economic development. The H2Fuel project at the Savannah River Site is a result of the technology transfer effort. The project was a joint effort among DOE, its contractor, industry, academia and local government. The objective was to convert a battery powered, 32-passenger transit bus into a hybrid hydrogen-powered bus. The bus would be used by the city of Augusta, Georgia, in its transit system.

The original electric bus was powered by four 28-battery packs, and had a driving range of about $130 \mathrm{~km}$. For the hybrid bus, two of the four battery packs (approximately $4,000 \mathrm{~kg}$ each pack) were replaced by hydride hydrogen storage vessels. An internal combustion engine and an electric generator were added. The hydride storage system stores and feeds hydrogen to the combustion engine. The engine and the generator produce electricity to power the electric drive motor and to charge the batteries. The batteries store the excess energy from the generator when the power demand is low and supply the needed energy when the power demand exceeds the capacity of the generator. This arrangement allows for the use of a small generator $(70 \mathrm{~kW})$ and a large electric drive motor $(170 \mathrm{~kW})$. A regenerative braking system is used to recover the waste energy. This hybrid power system permits the IC engine to run most efficiently, and is expected to extend the driving range of the original electric bus from $130 \mathrm{~km}$ to $200 \mathrm{~km}$. A photo of the bus and a schematic of the hybrid power system are shown in Figures 1 and 2, respectively.

New or improved technologies that are demonstrated on this bus include the metal hydride storage system, hydrogen engine conversion, on-board electric power generation and control, and emission reduction. This paper is concentrated on the on-board metal hydride storage system.

\section{On-Board Hydrogen Storage System Design Requirements}

When serving in the Augusta city transit system, the bus is expected to be started up in the morning and run for the day. At the end of the day it will be refueled and charged. To fulfill this operation plan, the hydride storage system must meet the following design requirements:

- Hydrogen storage capacity is for a full day's scheduled operation of the bus.

- The storage system does not add more weight to the original electric bus.

- Hydrogen pressure and flow rate meet the fuel requirements of the combustion engine.

- System is refueled once per day, refueling time to be compatible with the operation schedule.

- Engine coolant is used to provide heat for hydrogen desorption. 
- Utility water is used to remove heat during refueling through the use of an external heat exchanger.

- Refueling hydrogen is from a tube trailer or an electrolyzer.

To meet the above requirements, different metal hydrides and hydride vessel designs were considered. The chosen metal hydride and vessel design are described below.

\section{Metal Hydride Selection}

The metal hydride was selected using the follow criteria:

- The desorption hydrogen pressure must meet the engine feed requirement when heated by the engine coolant.

- The absorption pressure must be low so that refueling can be accomplished with hydrogen pressure less than 35 atm using utility water for cooling.

- The hydrogen weight content is greater than $1 \%$.

- The material is available commercially.

- The material is chemically stable at the operation conditions.

- The material can be activated to absorb hydrogen at moderate pressure and room temperature.

Lanthanum-nickel-aluminum type material has been used at the Savannah River Site for more than 15 years in various applications ${ }^{3,4}$. This type of material has been shown to have excellent chemical stability and was chosen to be the starting material for the bus project. To reduce the cost of the material, lanthanum was replaced with "lanthanum rich mischmetal" (designated symbol $\mathrm{Lm}$ ). The general formula was $\mathrm{Lm}_{\mathrm{x}} \mathrm{Ni}_{(5-\mathrm{y})} \mathrm{Al}_{\mathrm{y}}$. A value of $\mathrm{x}$ slightly larger than 1 was used to improve the material's performance ${ }^{5}$. The value of $y$ is adjusted for the required hydrogen pressure, since the hydrogen pressure increases with the decrease of the $y$ value ${ }^{6}$.

Three specific formulations were tried before the selection criteria were met. The compositions of these three materials are summarized in Table 1. The aluminum content varied from 0.3 to 0.04 . As expected the equilibrium hydrogen pressure increased as the aluminum content decreased. The hydrogen capacities of all three samples were essentially $0.9 \mathrm{H} / \mathrm{M}$ (hydrogen to metal atom ratio), or $1.3 \mathrm{wt} \%$. The final material selected for the onboard storage was sample 3 , whose formula is $\mathrm{Lm}_{1.06} \mathrm{Ni}_{4.96} \mathrm{Al}_{0.04}$. This material gives a favorable hydrogen capacity, rapid kinetics and easy activation, and meets all the selection criteria. The material was purchased from Ergenics, Inc., and was produced to specification by Japan Metals \& Chemicals Co., Ltd.

\section{Thermal Dynamic Properties of the Metal Hydride}

The absorption and desorption isotherms of the selected material (sample 3 in Table 1) are plotted in Figure 3 for $40^{\circ} \mathrm{C}$ and $60^{\circ} \mathrm{C}$. The ven't Hoff equation correlating the equilibrium 
temperature and pressure at the middle of the plateaus $(\mathrm{H} / \mathrm{M}=0.5)$ are represented by Equation 1 below:

$$
\ln P=-\Delta H /\left(R^{*} T\right)+\Delta S / R
$$

where $\mathrm{P}=$ pressure, atm

$\Delta \mathrm{H}=$ enthalpy, $6580 \mathrm{cal} / \mathrm{mol}$ for absorption, $6577 \mathrm{cal} / \mathrm{mol}$ for desorption

$\Delta \mathrm{S}=$ entropy, $25.56 \mathrm{cal} / \mathrm{mol} /{ }^{\circ} \mathrm{K}$ absorption, $24.91 \mathrm{cal} / \mathrm{mol} /{ }^{\circ} \mathrm{K}$ desorption

$\mathrm{R}=$ gas constant, $1.987 \mathrm{cal} / \mathrm{mol} /{ }^{\circ} \mathrm{K}$

\section{Hydride Activation}

The metal hydride material as received is stable in open air and is not reactive with hydrogen. An activation step is necessary before the material can absorb hydrogen readily. This usually involves evacuation (with or without heat), followed by exposure to hydrogen. The required vacuum, temperature and pressure of hydrogen are dependent on material. The conditions for activation of this material were determined by activating small $(5 \mathrm{~g})$ samples. In a stainless steel container the sample was evacuated at room temperature to approximately 0.5 torr for about 1 hour. It was then exposed to hydrogen from a known volume at a known pressure. The change in pressure as a function of time was recorded and used to measure the amounts of hydrogen absorbed by the metal hydride. The results of two tests with different hydrogen pressures are shown in Figure 4. The data showed that when exposed to 27 atm hydrogen pressure, the material began to absorb hydrogen after about 10 minutes and was almost saturated in about 60 minutes. When exposed to a lower pressure of $15 \mathrm{~atm}$, it took a little longer, about 45 minutes, to begin the absorption and was saturated in 3 hours. The results showed that this material can easily be activated with a moderate hydrogen pressure at room temperature. This simplifies the design and preparation of the hydride storage vessels.

\section{Hydride Vessel Design}

General technical issues encountered in the design of metal hydride vessels for on-board hydrogen storage include:

- The hydride particles expand upon hydrogen absorption and contract on desorption. This repeated size changing can cause compaction of the powder and possible swelling and consequent damage to the vessel.

- The metal hydride powder is a poor heat transfer medium. Slow heat transfer is usually the cause for slow hydrogen absorption and desorption.

- The metal hydride is a fine powder. A filter must be used to confine the particles. The filter must be effective in confining the particles but must not impede the flow of hydrogen.

- Metal hydride is heavy. The vessels must be light to minimize the total weight.

- The dimensions of the metal hydride vessels must fit the space available on the vehicle. 
With the above issues in consideration, the final design of the on-board hydrogen storage system consists of two "boxes" of metal hydride vessels. Each "box" contains 24 horizontally installed cylindrical vessels. The vessels are $9-\mathrm{cm}$ in diameter and $152-\mathrm{cm}$ long. They are assembled inside an aluminum box to form a stack of 6 vessels wide and 5 layers high. The aluminum boxes are $66 \mathrm{~cm}$ wide, $53 \mathrm{~cm}$ high, and $173 \mathrm{~cm}$ deep. All 24 vessels in a box are connected in parallel. The photo of a partly assembled box is shown in Figure 5. The boxes are installed below the bus floor on both sides of the chassis as shown in Figure 6.

The cylindrical hydride vessels are made from thin wall stainless steel, type 316L. The components inside each vessel include a porous stainless steel filter, 14 aluminum divider plates, 15 cylindrical aluminum foam pieces, and a U-shaped water tube. The filter permits hydrogen to flow freely in and out of the vessel but confines the metal hydride powders in the vessel. The divider plates separate the vessel into short sections to prevent the metal hydride powders from shifting among the sections. The aluminum foam pieces with metal hydride particles in their pores, improve the heat transfer between the hydride and the water tube. The engine coolant flows through the water tube to provide heat during desorption and to remove heat during absorption of hydrogen.

Limited by weight, only 2 boxes of vessels, or 48 of the originally planned 80 were installed on the bus. The total weight of the two boxes of hydride vessels is $1900 \mathrm{~kg}$, about the same as the two packs of batteries which they replaced. The metal hydride weight is $1250 \mathrm{~kg}$, or $66 \%$ of the total weight. The hydrogen capacity is $15 \mathrm{~kg}$ compared to the bus gross weight of $15000 \mathrm{~kg}$.

\section{Hydrogen Desorption Rate and Heat Transfer}

When running at full power, the hydrogen combustion engine was expected to require a hydrogen feed rate of $6 \mathrm{~kg} / \mathrm{hr}$ at a supply pressure of $10 \mathrm{~atm}$. The hydrogen storage system must desorb the hydrogen to support this rate. Hydrogen desorption consumes heat: The heat is transferred from the coolant to the metal hydride, and the rate must keep up with the heat consumed by the hydrogen desorption. Otherwise the metal hydride temperature will drop, causing the hydrogen pressure to drop also. To assure that the design can desorb 6 $\mathrm{kg} / \mathrm{hr}$ of hydrogen, the following calculations and development work were conducted:

The heat transfer rate required is equal to the hydrogen rate multiplied by the heat of desorption:

$$
6 \mathrm{~kg} / \mathrm{hr} * 6.6 \mathrm{kcal} / \mathrm{mole} * 1000 \mathrm{~mole} / 2 \mathrm{~kg}=19800 \mathrm{kcal} / \mathrm{hr}
$$

This heat transfer rate must be met by the heat transfer from the coolant to the metal hydride, $\mathrm{q}$, which can be calculated from the following equation:

where

$$
q=U^{*} A^{*}\left(T_{c}-T_{e}\right)
$$

$\mathrm{q}=$ heat transfer rate, $\mathrm{kcal} / \mathrm{hr}$ 
$\mathrm{U}=$ overall heat transfer coefficient between the coolant and the metal hydride, $\mathrm{kcal} / \mathrm{hr} / \mathrm{m}^{2 /{ }^{\circ} \mathrm{C}}$

$\mathrm{A}=$ heat transfer area, $\mathrm{m}^{2}$

$\mathrm{T}_{\mathrm{c}}=$ coolant temperature or target engine operating temperature, $70^{\circ} \mathrm{C}$

$\mathrm{T}_{\mathrm{e}}=$ equilibrium temperature of the metal hydride at 10 atm hydrogen desorption pressure, $51^{\circ} \mathrm{C}$ (from equation 1 )

In Equation 2 let $q$ be the required heat rate of $19800 \mathrm{kcal} / \mathrm{hr}$, the required value of $\mathrm{U}^{*} \mathrm{~A}$ is calculated to be $1042 \mathrm{kcal} / \mathrm{hr} /{ }^{\circ} \mathrm{C}$. This value must be satisfied by the design of the hydride vessel. Let us start with the basic dimensions of the hydride vessels and the number of vessels. As it has been described earlier, the two boxes contains a total of 48 hydride vessels. Each vessel has a U-shaped coolant tube to circulate the coolant. The total length of the coolant tubes in all 48 hydride vessels is $146 \mathrm{~m}$ long, which gives a total inside surface area (A) of $5.85 \mathrm{~m}^{2}$. All the heat required for the desorption of hydrogen must be transferred through this surface. The required overall heat transfer coefficient $(U)$ based on this inside surface area is the value of $\mathrm{U}^{*} \mathrm{~A}$ divided by $\mathrm{A}$, and is $178 \mathrm{kcal} / \mathrm{hr} / \mathrm{m}^{2} /{ }^{\circ} \mathrm{C}$

The actual overall heat transfer coefficient is determined by three individual heat transfer coefficients: $h_{1}$ for the coolant to the coolant tube inside surface, $h_{2}$ for the tube wall, and $h_{3}$ for the tube outside surface to the metal hydride. The value of $h_{1}$ is dependent on the coolant flow velocity in the tubes. For 24 tubes connected in parallel at a total coolant flow rate of 150 liter/min, the coolant flow velocity is calculated to be $0.82 \mathrm{~m} / \mathrm{sec}(2.7 \mathrm{ft} / \mathrm{sec})$. The heat transfer coefficient at this flow rate is calculated to be $4986 \mathrm{kcal} / \mathrm{hr} / \mathrm{m}^{2} /{ }^{\circ} \mathrm{C}\left(5800 \mathrm{~W} / \mathrm{m}^{2} /{ }^{\circ} \mathrm{K}\right.$, $1021 \mathrm{Btu} / \mathrm{hr} / \mathrm{ft}^{2} /{ }^{\circ} \mathrm{F}$ ). The value of $\mathrm{h}_{2}$ is calculated from the thermal conductivity of stainless steel and the wall thickness, and is $8899 \mathrm{kcal} / \mathrm{hr} / \mathrm{m}^{2} /{ }^{\circ} \mathrm{C}\left(10350 \mathrm{~W} / \mathrm{m}^{2} /{ }^{\circ} \mathrm{K}, 1823 \mathrm{Btu} / \mathrm{hr} / \mathrm{ft}^{2} /{ }^{\circ} \mathrm{F}\right)$.

Heat transfer between the tube surface and the metal hydride is complicated. A study conducted on a similar $8.9-\mathrm{cm}$ diameter hydride vessel showed that the heat transfer in a horizontal metal hydride vessel is dependent solely on the hydrogen pressure. An equation correlating the heat transfer coefficient to the hydrogen pressure was developed?:

where

$$
h=29.2 * \log P-41.3
$$

$\mathrm{h}=$ effective heat transfer coefficient between the container wall and the metal hydride, $\mathrm{kcal} / \mathrm{hr} / \mathrm{m}^{2} /{ }^{\circ} \mathrm{C}$

$\mathrm{P}=$ hydrogen pressure, torr.

Equation 3 is used here to calculate the value for $h_{3}$. At a hydrogen pressure of $10 \mathrm{~atm}$ (7600 torr), the effective heat transfer coefficient is calculated to be $72 \mathrm{kcal} / \mathrm{hr} / \mathrm{m}^{2} /{ }^{\circ} \mathrm{C}(83.4$ $\mathrm{W} / \mathrm{m}^{2} /{ }^{\circ} \mathrm{K}, 15 \mathrm{Btu} / \mathrm{hr} / \mathrm{ft}^{2} /{ }^{\circ} \mathrm{F}$ ). This value is much smaller than those calculated for $\mathrm{h}_{1}$ and $\mathrm{h}_{2}$ above. The heat transfer between the tube wall and the metal hydride is therefore the controlling step. The resistance to heat transfer from the other two steps can be neglected. This analysis indicated that if nothing is done in the design to improve $h_{3}$, the value of $U$ will only be $72 \mathrm{kcal} / \mathrm{hr} / \mathrm{m}^{2} /{ }^{\circ} \mathrm{C}$ versus 178 required. The heat transfer will be too slow to supply the required hydrogen to the engine. 
To increase the value of $U$, aluminum foam pieces were added to the vessel to improve the heat transfer in the metal hydride bed. To evaluate the effectiveness of the aluminum foam, a 14-cm single section experimental bed was first fabricated and tested. The results showed that the aluminum foam increases the heat transfer coefficient of the metal hydride bed by a factor of approximately 5. That gives an overall heat transfer coefficient of $72 * 5=360 \mathrm{kcal} / \mathrm{hr} / \mathrm{m}^{2} /{ }^{\circ} \mathrm{C}$, which is about two times the required value of $178 \mathrm{kcal} / \mathrm{m}^{2} / \mathrm{hr} /{ }^{\circ} \mathrm{C}$. With this higher heat transfer rate, the two boxes of 48 hydride vessels can support a hydrogen feed rate of 12 $\mathrm{kg} / \mathrm{hr}$, versus the target rate of $6 \mathrm{~kg} / \mathrm{hr}$. The aluminum foams can improve the heat transfer rate to exceed the design goal.

\section{Safety Aspects}

Safety issues related to the on-board hydride hydrogen storage system are vessel integrity, over pressure and leaks. The design pressure of the hydride vessels was set at $35 \mathrm{~atm}$ absolute. Stress analyses were conducted to verify that the completed vessel will withstand the design pressure. A fully charged and closed vessel, when heated with the maximum coolant temperature, can generate a pressure exceeding the 35 atm design pressure. A release valve was installed on the vessel manifold to prevent the pressure from exceeding the design pressure. To avoid a sudden release of large amounts of bydrogen in the event of a line break, an excess flow valve was installed at the outlet of the manifold. This valve will close immediately when there is a sudden surge of flow. It will reopen automatically when the pressure difference between the two sides disappears. For slow leaks, hydrogen monitors were installed at strategic locations to detect the presence of hydrogen. When any of the monitors goes off, the bus will be evacuated and re-approached using predetermined procedures.

\section{Performance}

The H2Fuel bus has undergone driving tests in the streets of Augusta since April 1997, accumulating more than $1000 \mathrm{~km}$ of travel distance at the time of this writing. The on-board hydrogen storage vessels have been refueled over 20 times. What follows is a brief description on the performance of the hydrogen storage system in the area of activation, refueling, and feeding hydrogen to the combustion engine.

\subsection{ACTIVATION}

Activation of the on-board metal hydride vessels was accomplished by 5 steps: (1) Evacuate the air from the vessels to a vacuum of less than 10 torr; (2) Back fill the hydride vessels with hydrogen to about $5 \mathrm{~atm}$ and evacuate the hydrogen, and repeat the hydrogen purge twice; (3) Expose the metal hydride in the vessels to 18 atm hydrogen pressure, and flow water through the water tubes at approximately 35 liter/minute to provide cooling; (4) Let absorption to reach $50 \%$ of capacity, then vent the hydrogen to atmosphere; (5) Repeat step 4 but let the absorption to reach $75 \%$. After step 5, the hydride vessels were ready to take a full charge 
and to fuel the engine operation. The purpose of partial saturation in steps 4 and 5 was to let the metal hydride particles in the vessels to work into their final condition in steps.

As expected from the results of the small sample tests, the hydride began to absorb hydrogen after an incubation time of less than 15 minutes. Once the absorption started, the hydrogen was absorbed as fast as it could flow through a 7-meter long, 1-cm diameter tubing.

\subsection{HYDROGEN FEED RATE}

Operation data collected to date have shown that the hydrogen storage system can supply hydrogen to the engine at a rate exceeding the design goal. Listed in Table 2 is a set of data generated when only half of the storage vessels were used to feed the engine. Note that the average coolant temperature was only $60^{\circ} \mathrm{C}$, instead of the original target of $70^{\circ} \mathrm{C}$. From this set of data the heat transfer coefficient for the hydride vessel was calculated to be 476 $\mathrm{kcal} / \mathrm{hr} / \mathrm{m}^{2} /{ }^{\circ} \mathrm{C}$ which is better than the $360 \mathrm{kcal} / \mathrm{hr} / \mathrm{m}^{2} /{ }^{\circ} \mathrm{C}$ calculated earlier from the $14-\mathrm{cm}$ single section experimental bed. Since the heat transfer coefficient required to support $6 \mathrm{~kg} / \mathrm{hr}$ feed was calculated to be $178 \mathrm{kcal} / \mathrm{hr} / \mathrm{m}^{2} /{ }^{\circ} \mathrm{C}$ (see earlier calculation), the storage system can therefore support a hydrogen feed rate of up to $16 \mathrm{~kg} / \mathrm{hr}$ at the original target coolant temperature of $70^{\circ} \mathrm{C}$.

\subsection{REFUELING}

Presently, a tube trailer supplies the refueling hydrogen. Connection between the hydrogen supply and the hydride storage system is accomplished by using a Sherex fueling nozzle and receptacle. The heat of absorption during refueling is removed via a water-cooled external heat exchanger. With a supply hydrogen pressure set at $18 \mathrm{~atm}$, the hydride can be charged to $75 \%$ full in about 60 minutes; another 60 minutes are needed to charge the other $25 \%$. The refueling time is just meeting the original target time of 2 hours.

\section{Conclusions}

An on-board hydrogen storage system using metal hydride has been successfully developed, fabricated and demonstrated on a city transit bus. Road testing to date has shown that the original design goals have been reached or exceeded. The use of metal hydride for on-board hydrogen storage gives a safety advantage and has a high potential to be successfully used in applications where weight is not a prohibitive factor. The hydrogen storage system in this project was developed for an IC engine, but it can be applied to a fuel cell powered system as well. When the fuel cell technology becomes more economical. The IC engine can be replaced with a fuel cell to further increase the energy efficiency.

\section{Acknowledgments}

This paper was prepared in connection with work done under Contract No. DEAC0996SR18500 with the U. S. Department Of Energy. The hydride storage vessels were 
fabricated by Hydrogen Components Inc. through a procurement order from the Westinghouse Savannah River Company. My colleague T. J. Warren conducted the hydride activation tests.

\section{References}

1. Topler J. and Feucht K.(1988) Results of a Test Fleet with Metal Hydride Motor Cars, Metal-Hydrogen Systems, vol. II, 1451-1461, Edited by R. Kirchheim, E. Fromm, and E Wiche, Stuttgart.

2. Das L. M. (1996) On-Board Hydrogen Storage System For Automotive Applications, Int. J. Hydrogen Energy, vol. 21, No. 9, 789-800.

3. Ortman M. S., Heung, L. K., Nobile A., and Rabun R. L. III (1990) Tritium Processing at the Savannah River Site: Present and Future, J. of Vacuum Science \& Technology A 8 (3), 2881-2889.

4. Motyka, T. (1992) The Replacement Tritium Facility, Fusion Technology, vol. 21, 247252.

5. Marmare R. W. and Lynch F. E. (1991) Investigation of Long Term Stability in Metal Hydrides, Final Report to NASA, NAS9-18175.

6. Diaz H., Percheron-Guegan A. and Achard J. C. (1979) Thermodynamic and Sturctural Properties of $\mathrm{LaNi}_{5-\mathrm{y}} \mathrm{Al}_{\mathrm{y}}$ Compounds and Their Related Hydrides, Int. J. of Hydrogen Energy, vol. 4, 445-454.

7. Heung L. K. (1988) Heat Transfer and Kinetics of a Metal Hydride Reactor, MetalHydrogen Systems, vol. II, 1451-1461, Edited by R. Kirchheim, E. Fromm, and E Wiche, Stuttgart. 
TABLE 1. Composition and properties of the H2Fuel metal hydride

\begin{tabular}{|c|c|c|c|c|}
\hline & & Sample 1 & Sample 2 & Sample 3 \\
\hline Formul & & $\mathrm{Lm}_{1.04} \mathrm{Ni}_{4.6}{ }_{9} \mathrm{Al}_{0.31}$ & $\mathrm{Lm}_{1.06} \mathrm{Ni}_{4.79} \mathrm{Al}_{0.21}$ & $\mathrm{Lm}_{1.06} \mathrm{Ni}_{4.96} \mathrm{Al}_{0.04}$ \\
\hline Elements(wt\%) & $\mathrm{La}$ & 17.51 & 18.09 & 18.86 \\
\hline & $\mathrm{Ce}$ & 1.28 & 1.04 & 0.84 \\
\hline & $\operatorname{Pr}$ & 2.76 & 2.90 & 2.60 \\
\hline & $\mathrm{Nd}$ & 11.63 & 11.85 & 11.58 \\
\hline & $\mathrm{Ni}$ & 65.014 & 64.65 & 65.87 \\
\hline & $\mathrm{Al}$ & 1.95 & 1.30 & 0.25 \\
\hline Molecular Weig & & 430.4 & 436.6 & 441.9 \\
\hline $\begin{array}{l}60^{\circ} \mathrm{C} \text { Absorptio } \\
\text { at } 0.5 \mathrm{H} / \mathrm{M} \text { (atm }\end{array}$ & & 5.2 & 6.1 & 18.5 \\
\hline $60^{\circ} \mathrm{C}$ Desorpti & & & & \\
\hline at $0.5 \mathrm{H} / \mathrm{M}$ (atm & & 4.4 & 4.7 & 13.5 \\
\hline Hydrogen Capa & & & & \\
\hline $\begin{array}{l}\mathrm{H} / \mathrm{M} \text { at } 40^{\circ} \mathrm{C}, 2 \\
\text { (wt\%) }\end{array}$ & atm & $\begin{array}{c}0.93 \\
(1.30)\end{array}$ & $\begin{array}{c}0.92 \\
(1.28)\end{array}$ & $\begin{array}{c}0.92 \\
(1.27)\end{array}$ \\
\hline
\end{tabular}

TABLE 2. Heat transfer and hydrogen feed rate data

\begin{tabular}{lc}
\hline Coolant temperature in coolant tube & $\begin{array}{c}\text { inlet }=65.5^{\circ} \mathrm{C} \text {, outlet }=54.4^{\circ} \mathrm{C} \\
\text { average }=60^{\circ} \mathrm{C}\end{array}$ \\
$\begin{array}{l}\text { Average hydrogen feed rate from } 1 / 2 \text { of the vessels } \\
\text { over a one hour period }\end{array}$ & $51{ }^{\circ} \mathrm{C}$ \\
$\begin{array}{l}\text { Hydride temperature in equilibrium with } 10 \mathrm{~atm} \\
\text { hydrogen pressure }\end{array}$ & $12540 \mathrm{kcal} / \mathrm{hr}$ \\
$\begin{array}{l}\text { Average heat transfer rate from coolant to hydride } \\
=3.8 \mathrm{~kg} / \mathrm{hr} * 6.6 \mathrm{kcal} / \mathrm{mole}^{*} 1000 \mathrm{~mole} / 2 \mathrm{~kg}\end{array}$ & $476 \mathrm{kcal} / \mathrm{hr} / \mathrm{m}^{2} /{ }^{\circ} \mathrm{C}$ \\
$\begin{array}{l}\text { Overall heat transfer coefficient } \\
=12540 \mathrm{kcal} / \mathrm{hr} /\left(60^{\circ} \mathrm{C}-51^{\circ} \mathrm{C}\right) /\left(5.85 \mathrm{~m}^{2} / 2\right)\end{array}$ & \\
\hline
\end{tabular}




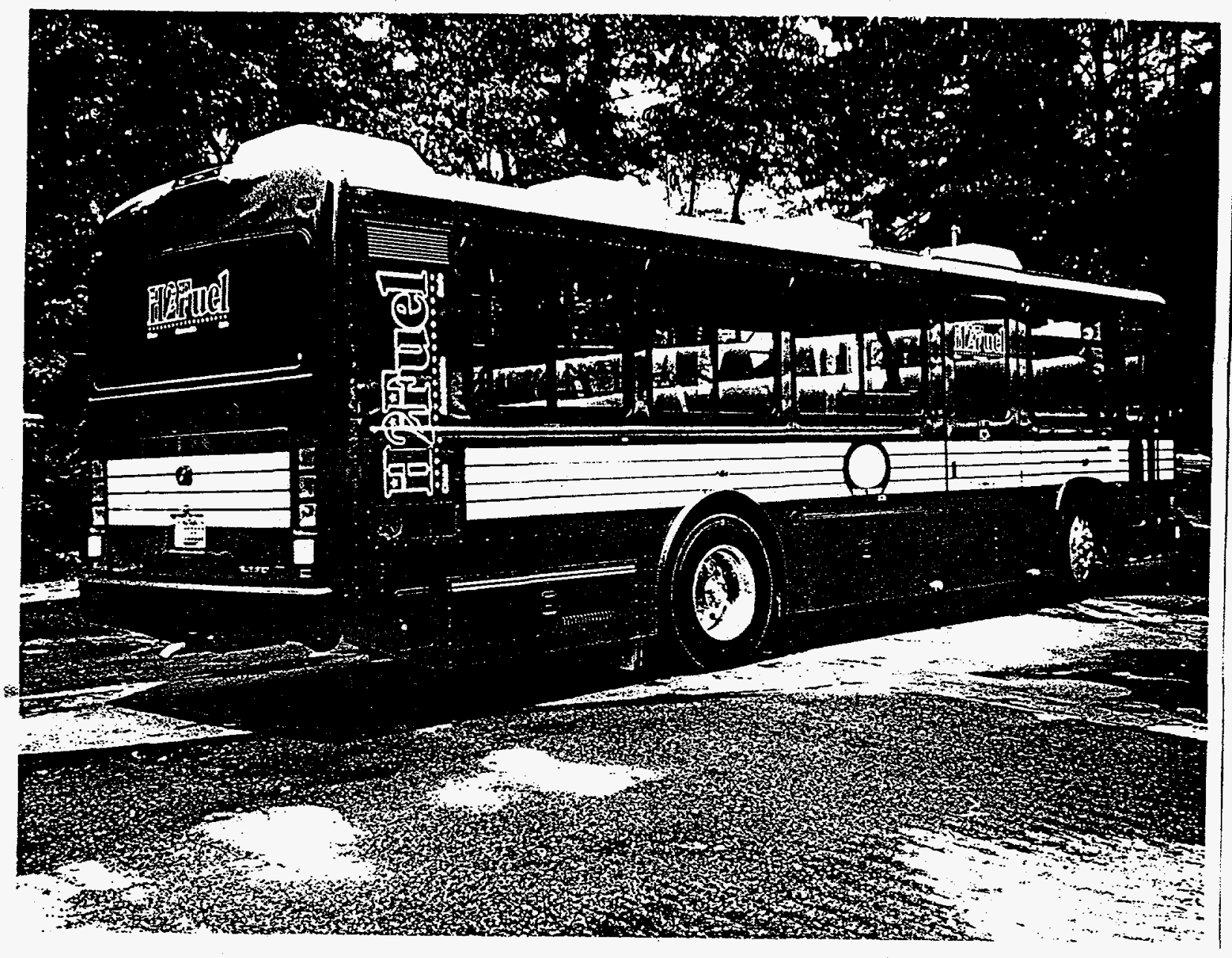

Figure 1. The H2Fuel hydrogen powered hybrid Bus 


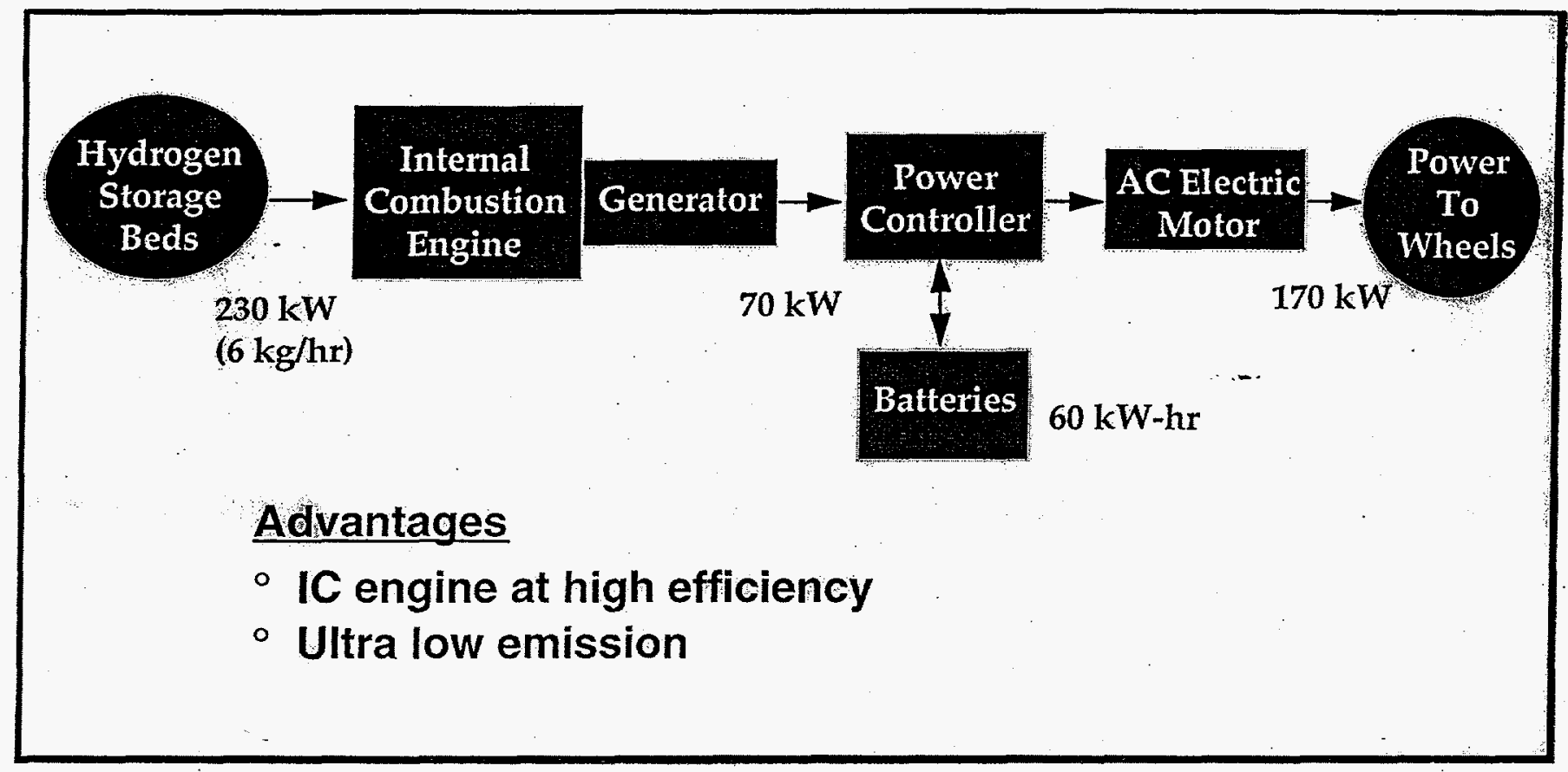

Figure 2. Schematic of the hydrogen powered hybrid power system 


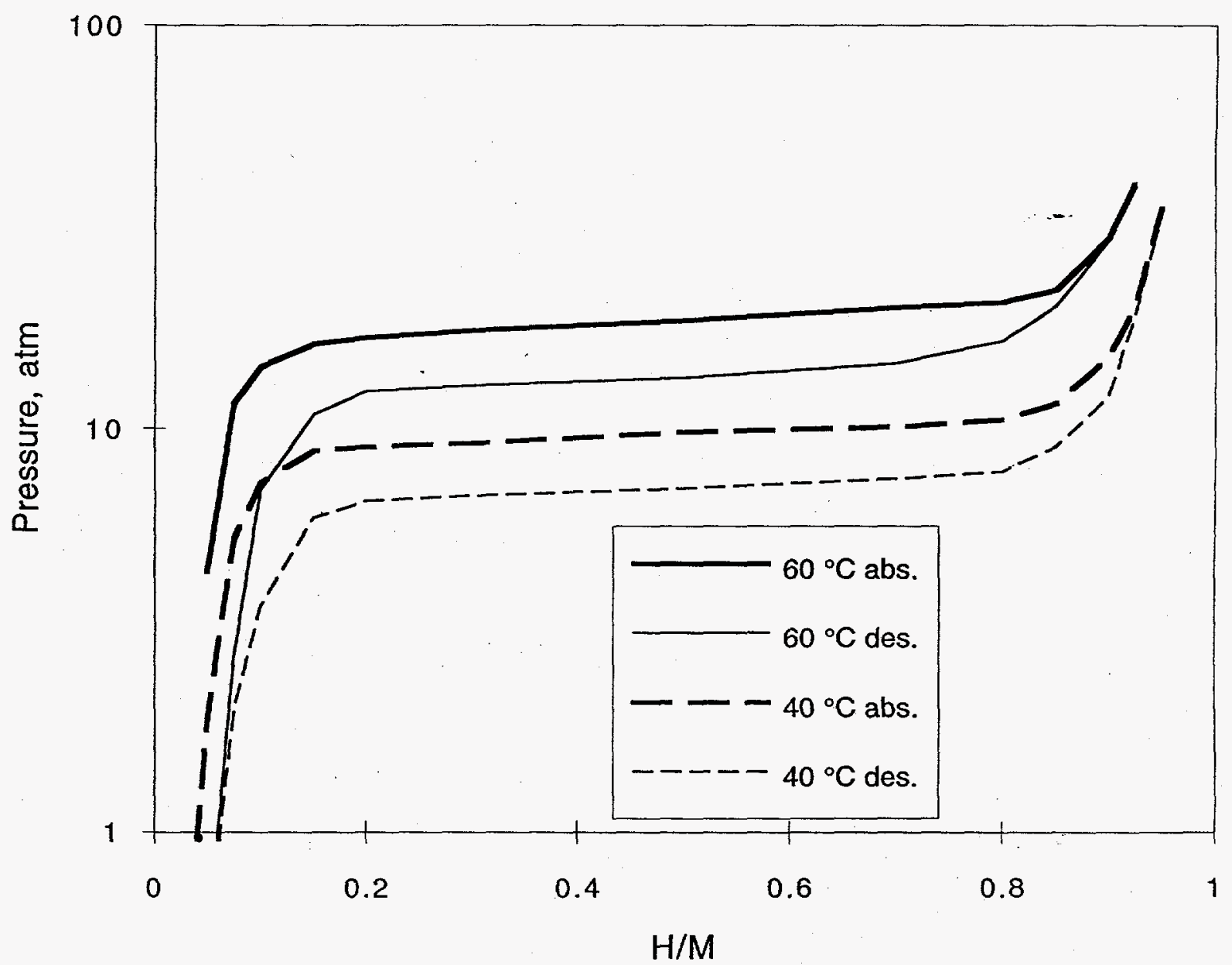

Figure 3. Absorption and desorption isotherms of $\mathrm{Lm}_{1.06} \mathrm{Ni}_{4.96} \mathrm{Al}_{0.04}$ 


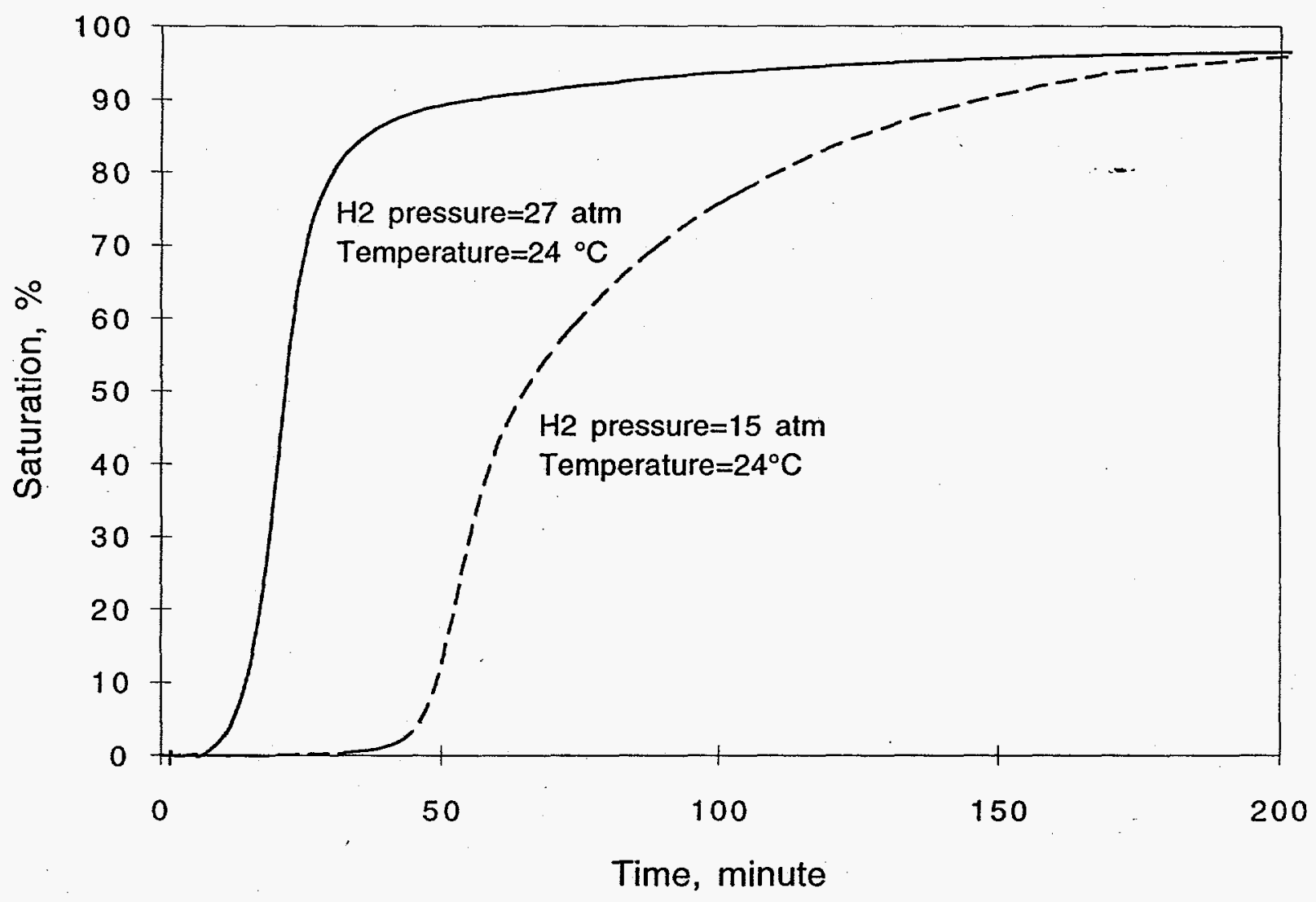

Figure 4. Activation of $\mathrm{Lm}_{1.06} \mathrm{Ni}_{4.96} \mathrm{Al}_{0.04}$ 


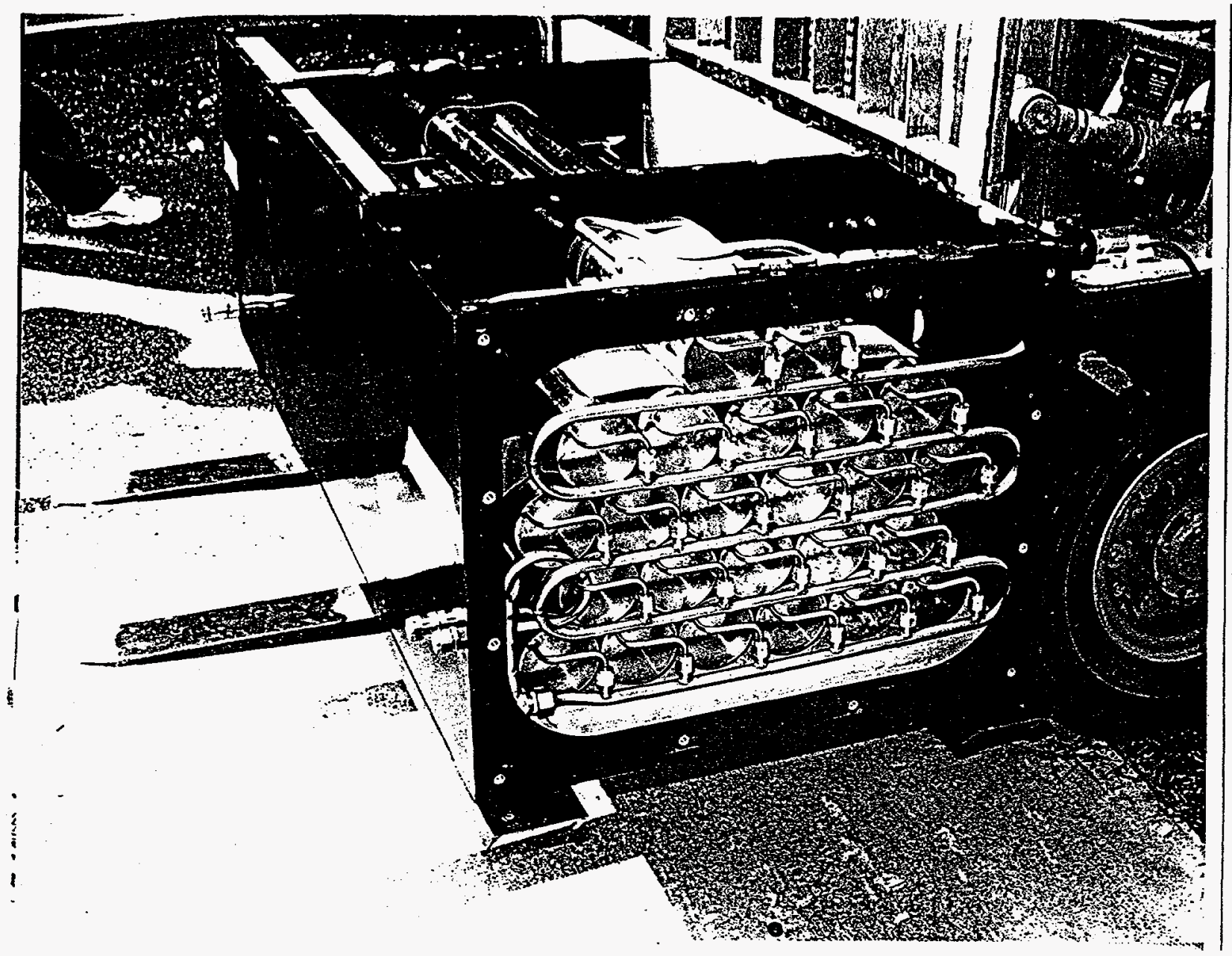

Figure 5. The on-board hydride hydrogen storage vessels 


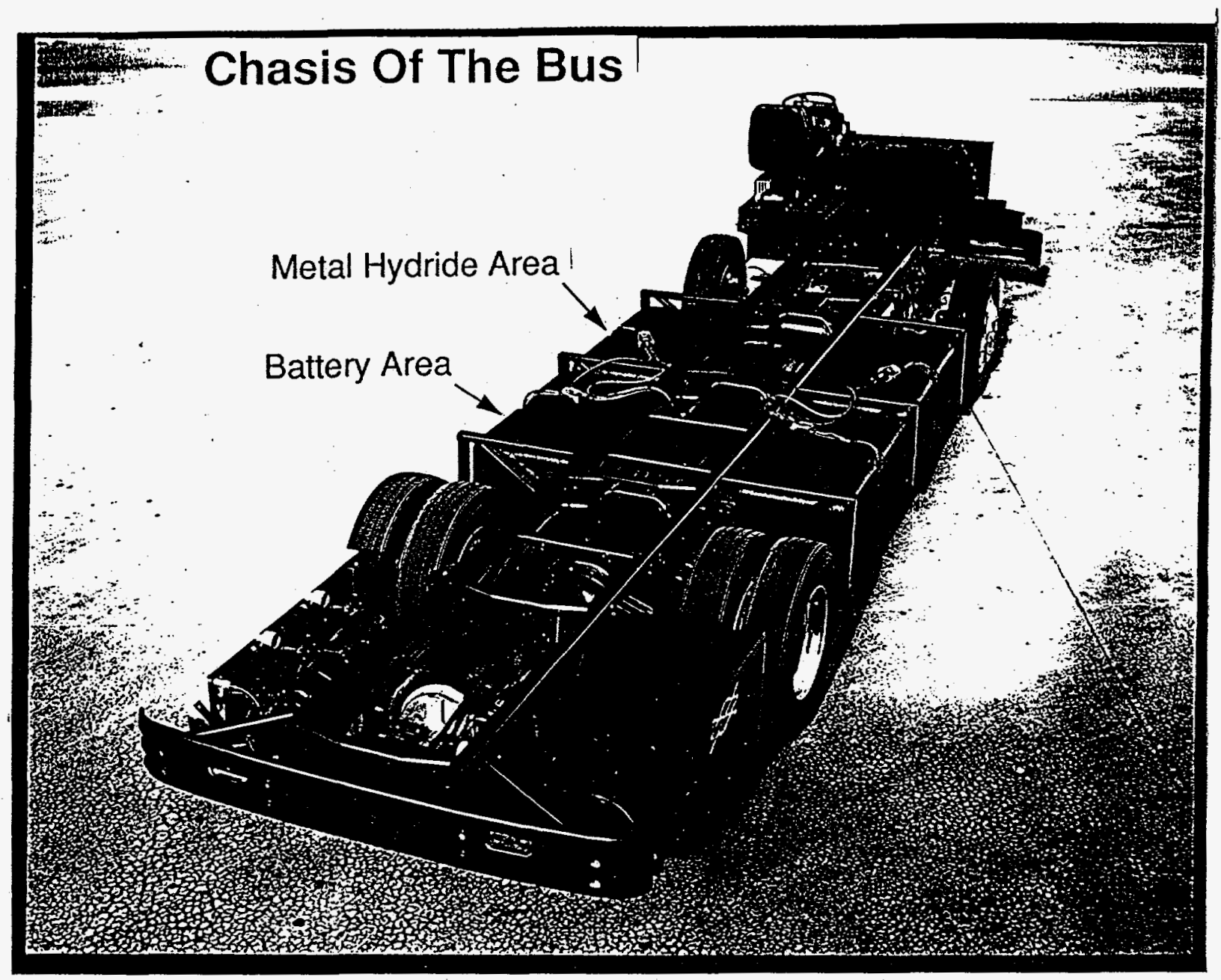

Figure 6. Location of the hydride hydrogen storage vessels 